\title{
Effect of Degumming and Catalyst Type on Physiochemical and Biodiesel Properties of Tropical-Almond (Terminalia catappa) Seed Oil
}

\author{
${ }^{*}$ SANI, L; ${ }^{2}$ AJIBOLA, VO; ${ }^{2}$ ABECHI, SE \\ ${ }^{1}$ Department of Chemistry, Nigerian Military School, Zaria, Nigeria \\ ${ }^{2}$ Department of Chemistry, Ahmadu Bello University, Zaria, Nigeria \\ "Corresponding Author Email: elsani56@yahoo.com; Tel: +2348038385166
}

\begin{abstract}
This study investigates the effect of degumming process and catalyst type on physiochemical and biodiesel properties of tropical-almond (Terminalia catappa) seed oil (TCSO) extracted via mechanical pressing and solvent extraction method. The oil was degummed using $4 \%$ citric acid in amount of $10 \%$ by volume of the oil to reduce the acid value, ash content, and water and sediment value of the degummed oil compared to the raw oil. Data obtained show that degumming process reduces the acid value, ash content and water and sediment value from $7.57 \mathrm{mg} \mathrm{KOH} / \mathrm{g}$, $0.86 \% \mathrm{w} / \mathrm{w}$ and $2.48 \%$ to $3.82 \mathrm{mg} \mathrm{KOH} / \mathrm{g}, 0.65 \% \mathrm{w} / \mathrm{w}$ and $2.40 \%$ respectively, and the percentage oil yield was $56.30 \pm 1.50 \%$. Biodiesel was produced using a two-step reaction system from raw and degummed TCSO catalyzed by $\mathrm{NaOH}, \mathrm{KOH}$ and $\mathrm{CaO} / \mathrm{Al}_{2} \mathrm{O}_{3}$. The process yielded a higher yield (97.20 \pm 0.35 ) of biodiesel from degummed oil catalyzed by $\mathrm{CaO} / \mathrm{Al}_{2} \mathrm{O}_{3}$. The fuel properties of the biodiesels were found to fulfill both ASTM D6751 and EN14214 biodiesel standard except the raw biodiesel. this study confirm that degumming process improves the susceptibility of oil for biodiesel production and that heterogeneous base catalyst produce higher yield and quality fuel than their homogenous counterpart.
\end{abstract}

\section{DOI: https://dx.doi.org/10.4314/jasem.v22i12.7}

Copyright: Copyright $(9) 2018$ Sani et al. This is an open access article distributed under the Creative Commons Attribution License (CCL), which permits unrestricted use, distribution, and reproduction in any medium, provided the original work is properly cited.

Dates: Received: 25 November 2018; Revised: 09 December 2018; Accepted 20 December 2018

Keywords: Degummed, Transeterification, Biodiesel, Catalyst, Raw oil, unsaturation

The ever-increasing competing demand for energy sources, coupled with the fact that fossil fuel is nonrenewable, has led to the prediction that world's reserves of fossil fuel would be expended before the end of the 21st century (Shahriar and Erkan, 2009). Petroleum crises, which include uncertainties concerning petroleum fuels availability, environment issues due to increase in Green House Gas (GHG) emission, ozone layer depletion and increasing concern over global warming pose a great risk. Also the high production cost of biodiesel emanating mainly from the feed stock and the use of edible oils could lead to food crisis. All these contending issues are worldwide concerns and have led to the global shift in reliance on fossil fuel to more environmentally friendly and sustainable source of energy in order to fulfill an increasing energy demand. It has also become imperative to direct focus on mitigating the production cost, which is primarily due to the cost of raw material by the use of low cost feed stock (non-edible oil), and determination of the optimum reaction conditions at which increase in the yield of the methyl ester (biodiesel) could be achieved in order to supplement the conventional petrol diesel. Research in this area has been centered on discovering and improving feedstock for biodiesel production. Several articles have been published with the aim of improving on the yield and fuel properties of biodiesel produced from different vegetable oils (Odeigah et al., 2012; Knothe et al., 2009; Knothe, 2008; Voca et al., 2008).The utilization of Terminalia catappa which belong to the family Combretaceae, a source of non-edible vegetable oil as a raw material for biodiesel production in Nigeria will not affect food security. It will reduce biodiesel production cost and ensure its sustainability and availability. It will also give rise to availability of alternative fuel that meets ASTM standard which is renewable, environmentally friendly and affordable, hence mitigating greenhouse effect and redeeming our climate. The aim of this study is to investigate the effect of degumming and catalyst type on physiochemical and biodiesel properties of Tropicalalmond (Terminalia catappa) seed Oil.

\section{MATERIALS AND METHOD}

Materials: Fully matured Tropical-almond fruits (Terminalia catappa) were collected within the premises of Ahmadu Bello University main Campus Zaria, Kaduna State, Nigeria. The edible portion (flesh) was manually removed, leaving the stony shell containing the seed. The stony shell was carefully cracked to remove the groundnut-like seed. $5 \mathrm{~kg}$ of 
almond seeds were gathered and sun-dried for two weeks before being milled using domestic blender. The resulting powder was preserved in airtight sample bottles under cool condition in preparation for oil extraction (Giwa and Ogunbona, 2014).

Oil Extraction: The oil was extract by a mechanical pressing machine at the National Research Institute for Chemical Technology (NARICT), Zaria. The expelled oil was filtered using a muslin sieve into a beaker. The pulp was then dissolved in cyclohexane to extract the remaining oil. The pulp was filtered out from the solution. The remaining oil and cyclohexane were separated by means of distillation. The percentage oil yield was then calculated thus:

Oil yield $(\%)=\frac{\text { weight of oil }(\mathrm{g})}{\text { weight of ground seed }(\mathrm{g})} \times 100$

Degumming of oil: $1000 \mathrm{~g}$ of the oil was preheated to $80{ }^{\circ} \mathrm{C}$, water solution of citric acid (4\%) was then added in amount of $10 \%$ (by volume of oil). The mixture was stirred for 20 minutes. The oil/acid mixture was transferred to a holding vessel to settle for 60 minutes after which the degummed oil was separated from its by-products. The same procedure was repeated once for the degummed oil.

Physiochemical properties of the oil: The physiochemical properties of the oil were conducted in accordance with standard test method described in the AOCS (1998). The properties are density, acid value, kinematic viscosity, water and sediment, iodine value, saponification value and ash content

Preparation of $\mathrm{CaO} / \mathrm{Al}_{2} \mathrm{O}_{3}$ Catalyst: $15 \mathrm{~g}$ of hydrated lime was dissolve in $500 \mathrm{ml}$ beaker with distilled water. After thorough mixing, $85 \mathrm{~g}$ of alumina was added and stirred. The mixture was dried over a magnetic stirrer. The dried mixture was loaded into a crucible and was calcined in a muffle furnace at $700^{\circ} \mathrm{C}$ for 90 minutes. The calcined catalyst was grounded into powder.

Esterification procedure: The \%FFA of raw and degummed oil (Table 1) are higher than the value $(<1 \%)$ required for direct transesterication reaction (Balat and Balat, 2010). Hence necessitated the production of biodiesel by two stage methods; first by esterification, followed by transesterification. The acid esterification was conducted according to previously published procedure in which a mixture of $2.25 \mathrm{~g}$ methanol and $0.05 \mathrm{~g}$ conc. sulphuric acid was added for each gram of free fatty acid in the oil and warmed for 15 minutes on a hot plate. This mixture was then transferred slowly into the $250 \mathrm{~cm}^{3}$ conical flask containing the oil followed by the addition of methanol
$(20.0 \mathrm{~g})$ and stirred $(800 \mathrm{rpm})$ for 1 hour at $60^{\circ} \mathrm{C}$ to esterify (Garpen et al., 2004). At the end of the reaction, the resulting mixture was transferred into a holding vessel and allowed to stand for 1 hour after which the methanol-water mixture which rose to the top was decanted. The bottom fraction was now the pre-treated oil and the \% FFA was determined again in order to ensure it was less than $1.0 \%$ before base transesterification of the oil.

Transesterification: The method of laboratory scale biodiesel production employed by Maher et al., (2006) was adopted. Exactly $20 \mathrm{~g}$ of methanol was poured into a plastic container. $1 \mathrm{~g}$ of the catalyst $(\mathrm{NaOH})$ was carefully added to the plastic container and secured tightly. The container was placed on a shaker for about 5 minutes until the $\mathrm{NaOH}$ completely dissolved in the methanol, forming sodium methoxide. $100 \mathrm{~g}$ of Terminalia catappa seed oil pre heated to $60^{\circ} \mathrm{C}$ was poured into an electric blender. The prepared sodium methoxide from the plastic container was carefully poured into the blender. The blender was secured tightly, switch on at full agitation speed and the agitation was maintained for 30 minutes. The resulting product was poured into a separating funnel and allowed to stand. The glycerin was tapped off, leaving the biodiesel in the separating funnel. The biodiesel was washed with warm distilled water to remove trace amounts of catalyst and glycerol in the methyl ester. The same procedure was repeated using $\mathrm{KOH}$ and $\mathrm{CaO} / \mathrm{Al}_{2} \mathrm{O}_{3}$ catalyst. The percentage yield of biodiesel (fatty acid methyl ester) was calculated as:

$$
\text { Yield }(\%)=\frac{\text { weight of biodiesel produced }}{\text { Weight of oil used }} \times 100
$$

Biodiesel fuel characterization: Biodiesel properties of raw and degummed Terminalia catappa oil methyl ester were determined according to ASTM (2008) test methods (ASTM D6751). The following properties were measured experimentally: acid value(ASTM D664), density (ASTM D5002), kinematic viscosity (ASTM D445), iodine value, pour point (D5949), cloud point (ASTM D2500), flash point (ASTM D93), cetane number (ASTM D613), oxidative stability (EN14112), water and sediment (ASTM D2709), heating value (ASTM D4809) and ash content (ASTM D874).

\section{RESULT AND DISCUSSION}

Oil content and Physiochemical properties of Terminalia catappa seed oil: The oil content of Terminalia catappa seed $56.30 \pm 1.50 \%$ obtained in this work is similar to the oil yield of T. catappa $55.05 \%$ reported by Oderinde R.A (1998) and higher than the range (49.0-51.80\%) reported previously (Giwa and 
Ogunbona 2004; Dos Santos et al., 2008; Matos, et al., 2008). This could be attributed to the extraction method employed in producing TCSO, location of sample collection and soil type. The acid values of raw and degummed TCSO are $7.57 \pm 0.24 \mathrm{mg} \mathrm{KOH} / \mathrm{g}$ and $3.82 \pm 0.13 \mathrm{mg} \mathrm{KOH} / \mathrm{g}$ respectively. The acid value of the oil is far greater than the recommended value of $2.0 \mathrm{mgKOH} / \mathrm{g}$ for alkaline direct transesterification and therefore will require esterification before it can be transesterified into biodiesel (Conakci and Van
Gerpen, 2001). Degumming process does not affect the value of density and viscosity of the oil, but it slightly reduces the water and sediment value, iodine value, saponification value and ash content of the degummed oil compared to the raw oil. The lower moisture and ash content of the degummed oil makes it more suitable for biodiesel production compared to the raw oil.

Table 1. Physiochemical properties and fatty acid profile of raw and degummed Terminalia catappa seed oil

\begin{tabular}{|c|c|c|}
\hline Properties & raw oil & Degummed oil \\
\hline Density $\mathrm{gcm}^{-3}$ & $0.881 \pm 0.02$ & $0.881 \pm 0.02$ \\
\hline Acid value $\mathrm{mgkOH} / \mathrm{g}$ & $7.57 \pm 0.24$ & $3.82 \pm 0.13$ \\
\hline FFA $\%$ & $3.79 \pm 0.14$ & $1.91 \pm 0.12$ \\
\hline Viscosity at $40^{\circ} \mathrm{C} \mathrm{mm}^{2} / \mathrm{s}$ & $46.00 \pm 1.00$ & $46.00 \pm 1.00$ \\
\hline Water and sediment $\%$ w/w & $2.48 \pm 0.20$ & $2.40 \pm 0.21$ \\
\hline Iodine value $\mathrm{gI}_{2} / 100 \mathrm{~g}$ of oil & $82.42 \pm 0.51$ & $78.80 \pm 0.62$ \\
\hline Saponification value $\mathrm{mgkOH} / \mathrm{g}$ & $195.37 \pm 0.70$ & $192.57 \pm 0.65$ \\
\hline Ash content $\% \mathrm{w} / \mathrm{w}$ & $0.86 \pm 0.02$ & $0.65 \pm 0.02$ \\
\hline Fatty Acid (Class) & wt $\%$ & wt $\%$ \\
\hline Myristic (14:0) & 1.62 & 1.32 \\
\hline Palmitic (16:0) & 33.65 & 37.50 \\
\hline Palmitoleic (16:1) & 0.66 & 0.74 \\
\hline Stearic (18:0) & 7.26 & 8.23 \\
\hline Oleic $(18: 1)$ & 40.16 & 40.16 \\
\hline Linoleic $(18 ; 2)$ & 13.83 & 9.95 \\
\hline Arachidic $(20: 0)$ & 2.82 & 2.10 \\
\hline Saturated & 45.35 & 49.15 \\
\hline Mono - unsaturated & 40.82 & 40.92 \\
\hline Poly - unsaturated & 13.83 & 9.95 \\
\hline Total unsaturated & 54.65 & 50.85 \\
\hline
\end{tabular}

Fatty acid composition: The fatty acid profile of raw and degummed TCSO as analyzed by GC-MS are shown in Table 1 . The fatty acids comprises of myristic acid (C14:0), palmitic acid (C16:0), palmitoleic acid (C16:1), stearic acid (C18:0), oleic acid (C18:1), linoleic acid (C18:2) and arachidic acid (C20:0). The percentage composition of fatty acid obtained in this study was similar to those of other species of Terminalia catappa previously reported by (Dos Santos et al., 2008; Adewuyi et al., 2011, Ng et al., 2015) with the exception of sweat almond (Giwa and Ogunbona 2014). It was observed (from Table 1 and Fatty acids above) that degumming process slightly increased the level of saturation and reduced the total level of unsaturation of the degummed oil. The high percentage of saturated and monounsaturated fatty acid of Terminalia catappa seed oil indicates high heat of combustion of the oil (Oseni et al., 2012) which would be readily release during combustion, this property compliment other properties such as specific gravity, peroxide value, iodine value to make it a good potential for biodiesel production (Garpen et al., 2004).

Yield of Terminalia catappa methyl ester: Base catalyzed transesterification is preferred over acid catalyzed transesterification reaction for the production of biodiesel at industrial level because it provides better conversion rates and efficiencies (Fukuda et al., 2001). The percentage conversion yield of raw Terminalia catappa seed oil to biodiesel using $1 \% \mathrm{w} / \mathrm{w} \mathrm{NaOH}$ catalyst is $86.64 \pm 0.19 \%$. It was observed that the conversion of degummed oil to biodiesel gave higher percentage yield of $92.68 \pm 0.31 \%$ under the same reaction condition. High percentage increase in the biodiesel of the degummed oil indicate that degumming process led to the removal of high gummy materials and phospholipids in the oil thus enhancing its biodiesel conversion. Phospholipids and gummy materials present in raw oil might affect the transesterification reaction and may be the reason for the low yield of biodiesel observed. The result obtained agreed with the high biodiesel yield reported by (Aldo, et al., 2011; Adekunle, et al., 2016) for neutralized jatropha oil and some non-conventional oils than the raw oils. The degummed oil was also catalyzed with $1 \%$ w/w $\mathrm{KOH}$ and $\mathrm{CaO} / \mathrm{Al}_{2} \mathrm{O}_{3}$ catalyst to determine the effect of catalyst type on biodiesel yield of the degummed oil. The percentage yield of the biodiesel ranged from $95.50 \pm 0.26 \%$ for $\mathrm{KOH}$, $97.20 \pm 0.57 \%$ for $\mathrm{CaO} / \mathrm{Al}_{2} \mathrm{O}_{3}$ and $92.68 \pm 0.31 \%$ for $\mathrm{NaOH}$. A lower yield was observed for the alkaline 
catalyzed biodiesel, this may be as a result of water and soup formed during transesterification process.

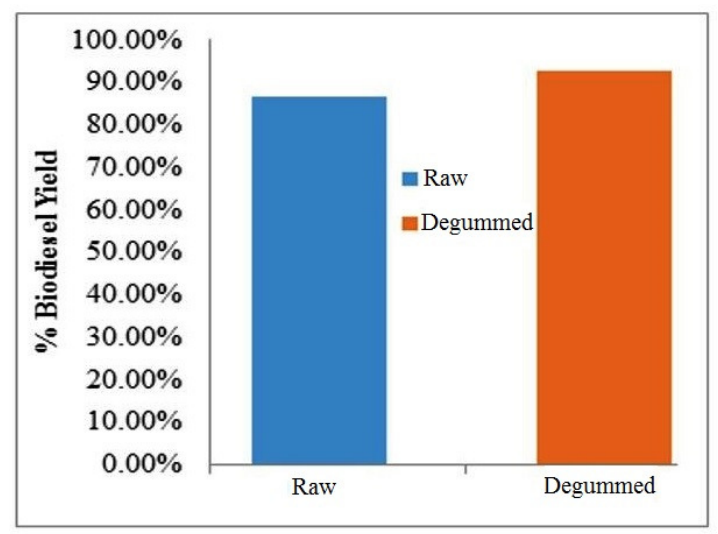

Fig 1: Effect of $\mathrm{NaOH}$ catalyst on Ester yield of raw and degummed Terminalia catappa seed oil (reaction conditions: methanol: oil = $6: 1$, catalyst concentration $=1 \% \mathrm{w} / \mathrm{w})$

Fuel properties of Terminalia catappa methyl ester: Acid value: Acid value is a measure of the number of acidic functional groups in a sample and is measured in terms of the quantity of $\mathrm{KOH}$ required to neutralize the sample (Cvengros, 1998). Usually for a base catalyzed process, the acid value after biodiesel production will be low since the base catalyst will strip the available free fatty acids (Gerpen et al., 2004). Considering the presence of free fatty acids influences fuel aging due to hydrolytic cleavage of ester bond. In 2006 the ASTM D6751 biodiesel acid number limit was harmonized with the European Union (EN14214) standard for biodiesel to a value of $\max 0.50$ $\mathrm{mgKOH} / \mathrm{g}$ (Mahajan et al., 2006).

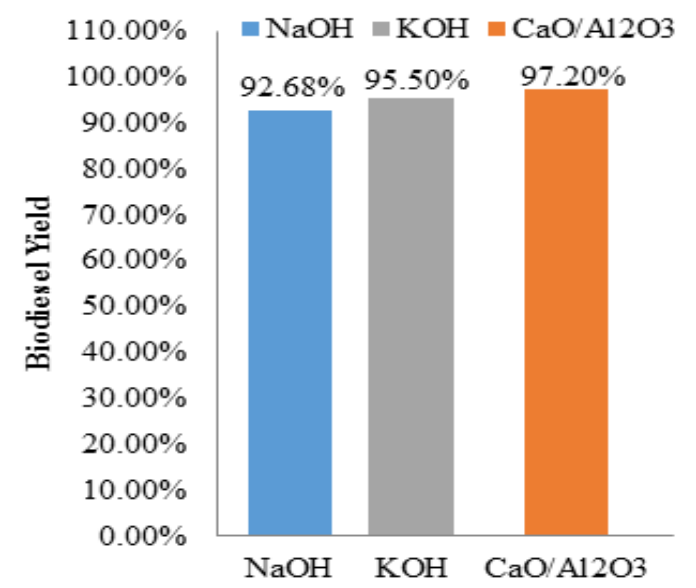

Figure 2 Effect of different catalyst on Ester yield of degummed Terminalia catappa seed oil (reaction conditions; methanol: oil = $6: 1$, catalyst concentration $=1 \% \mathrm{w} / \mathrm{w}$ )
The acid values of $\mathrm{NaOH}$ catalyzed raw and degummed biodiesel are $0.44 \pm 0.10 \mathrm{mgKOH} / \mathrm{g}$ and $0.28 \pm 0.21 \mathrm{mgKOH} / \mathrm{g}$ respectively (Table 2 ), while that of $\mathrm{KOH}$ and $\mathrm{CaO} / \mathrm{Al}_{2} \mathrm{O}_{3}$ catalyzed degummed biodiesel are $0.33 \pm 0.14 \mathrm{mgKOH} / \mathrm{g}$ and 0.18 $\pm 0.21 \mathrm{mgKOH} / \mathrm{g}$ respectively (Table 3 ). The decrease in the acid value of degummed biodiesels might be due decrease in free fatty acid present in the oil during degumming process. The lower acid value of $\mathrm{CaO} / \mathrm{Al}_{2} \mathrm{O}_{3}$ catalyzed degummed biodiesel suggests high resistance to corrosion due to decrease in free fatty acid content of the biodiesel. The acid value of all biodiesel samples in this study falls within the acceptable standard of both ASTM D6751 and EN14214biodiesel standard.

Density: Density is a key fuel property, which directly affect the engine performance. Fuel density directly affects fuel performance, and some of the engine properties such cetane number, heating value and viscosity are strongly connected to density. The density of the fuel also affects the quality of atomization and combustion (Barabas and Todorut, 2011). The Density limits of European standards range from $0.860-0.900 \mathrm{gcm}^{-3}$ (Meher et al., 2006). From this study the density of $\mathrm{NaOH}$ catalyzed Raw and degummed biodiesel are $0.860 \pm 0.012 \mathrm{gcm}^{-3}$ and $0.863 \pm 0.010 \mathrm{gcm}^{-3}$ respectively (Table 2 ). The density of $\mathrm{KOH}$ and $\mathrm{CaO} / \mathrm{Al}_{2} \mathrm{O}_{3}$ catalyzed degummed biodiesel are $0.865 \pm 0.010$ and $0.863 \pm 0.010 \mathrm{gcm}^{-3}$ respectively (Table 3 ). The densities of all biodiesel samples are within the acceptable EN standard and the values were very close, this may be due to the density of methanol used in their production and same fatty acid composition.

Kinematic viscosity: Viscosity is defined as the resistance of liquid to flow. It refers to the thickness of the oil, and is determined by measuring the amount of time taken for a given measure of oil to pass through an orifice of a specified sized (Raj and Sahayaraj, 2010). The viscosities of biodiesel at $40^{\circ} \mathrm{C}$ obtained in this study ranged from $3.71 \pm 0.82 \mathrm{~mm}^{2} / \mathrm{s}$ for $\mathrm{NaOH}$ catalyzed raw biodiesel, $4.60 \pm 0.50 \mathrm{~mm}^{2} / \mathrm{s}$ for $\mathrm{NaOH}$ catalyzed degummed biodiesel, $4.10 \pm 0.28 \mathrm{~mm} 2 / \mathrm{s}$ for $\mathrm{KOH}$ and $4.70 \pm 0.62 \mathrm{~mm}^{2} / \mathrm{s}$ for $\mathrm{CaO} / \mathrm{Al}_{2} \mathrm{O}_{3}$ catalyzed degummed biodiesel (Tables 2 and 3). According to ASTM D6751 and EN14214 standard for biodiesel, kinematic viscosity must be between $1.9-6.0 \mathrm{~mm}^{2} / \mathrm{s}$ and $3.5-5.0 \mathrm{~mm}^{2} / \mathrm{s}$ respectively. The viscosities of all biodiesel are within the range specified by ASTM D6751 and EN14214 standard. The increase in viscosities of degummed biodiesel might be as a result of decrease in degree of unsaturation of degummed oil. Thus biodiesel from raw oil have more potential for fuel application than those of degummed oil. 


\begin{tabular}{|c|c|c|c|c|c|}
\hline PROPERTIES & UNIT & CRUDE & DEGUM & $\begin{array}{l}\text { ASTM D6751 } \\
\text { STANDARD }\end{array}$ & $\begin{array}{l}\text { EN14214 } \\
\text { STANDARD }\end{array}$ \\
\hline Acid value & $\mathrm{mgkOH} / \mathrm{g}$ & $0.44 \pm 0.10$ & $0.28 \pm 0.21$ & $0.50 \max$ & $0.5 \max$ \\
\hline Density & $\mathrm{g} / \mathrm{cm}^{3}$ & $0.869 \pm 0.012$ & $0.863 \pm 0.010$ & $*$ & $0.86-0.90$ \\
\hline Viscosity $\left(40^{\circ} \mathrm{C}\right)$ & $\mathrm{Mm}^{2} / \mathrm{s}$ & $3.71 \pm 0.82$ & $4.60 \pm 0.50$ & $1.9-6.0$ & $3.5-5.0$ \\
\hline Iodine value & $\mathrm{gI}_{2} / 100 \mathrm{~g}$ of oil & $90.50 \pm 1.2$ & $72.42 \pm 1.50$ & $*$ & $120 \max$ \\
\hline Pour point & ${ }^{\circ} \mathrm{C}$ & $3 \pm 0.00$ & $2 \pm 0.00$ & $*$ & $*$ \\
\hline Cloud point & ${ }^{\circ} \mathrm{C}$ & $10.0 \pm 0.00$ & $8 \pm 0.00$ & -3 to 12 & $*$ \\
\hline Oxidative stability & $\mathrm{h}$ & 4.20 & 5.8 & $3 \mathrm{~min}$ & $6 \mathrm{~min}$ \\
\hline Flash point & ${ }^{\circ} \mathrm{C}$ & $158 \pm 1.65$ & $153 \pm 1.50$ & $93 \mathrm{~min}$ & $120 \mathrm{~min}$ \\
\hline Cetane number & & $49.78 \pm 1.82$ & $52.84 \pm 1.50$ & $47 \mathrm{~min}$ & $51 \mathrm{~min}$ \\
\hline Ash content & $\%$ mass & $0.018 \pm 0.002$ & $0.014 \pm 0.001$ & $0.02 \max$ & $0.02 \max$ \\
\hline Water and sediment & $\% \mathrm{Vol}$ & 0.06 & 0.04 & $0.05 \max$ & $0.05 \max$ \\
\hline Heat of combustion & $\mathrm{Mj} / \mathrm{kg}$ & $40.26 \pm 0.70$ & $42.76 \pm 0.52$ & $*$ & $*$ \\
\hline FFA & $\%$ & 0.22 & 0.14 & $<1 \%$ & $<1 \%$ \\
\hline Yield of Biodiesel & $\%$ & 86.64 & 92.68 & & \\
\hline
\end{tabular}

\begin{tabular}{|c|c|c|c|c|c|c|}
\hline PROPERTIES & UNIT & $\mathrm{NaOH}$ & КОH & $\mathrm{CaO} / \mathrm{Al}_{2} \mathrm{O}_{3}$ & $\begin{array}{l}\text { ASTM } \\
\text { Standard }\end{array}$ & $\begin{array}{l}\text { EN } \\
\text { Standard }\end{array}$ \\
\hline Acid value & $\mathrm{MgkOH} / \mathrm{g}$ & $0.28 \pm 0.21$ & $0.33 \pm 0.19$ & $0.18 \pm 0.14$ & $0.50 \max$ & $0.50 \max$ \\
\hline Density & $\mathrm{g} / \mathrm{cm}^{3}$ & $0.863 \pm 0.01$ & $0.865 \pm 0.011$ & $0.863 \pm 0.01$ & * & $0.86-0.90$ \\
\hline Viscosity $\left(40^{\circ} \mathrm{C}\right)$ & $\mathrm{Mm}^{2} / \mathrm{s}$ & $4.60 \pm 0.50$ & $4.10 \pm 0.28$ & $4.70 \pm 0.62$ & $1.9-60$ & $3.5-5.0$ \\
\hline Iodine value & $\mathrm{gI}_{2} / 100 \mathrm{~g}$ of oil & $72.42 \pm 1.50$ & $72.56 \pm 0.90$ & $70.42 \pm 1.20$ & $*$ & $120 \max$ \\
\hline Pour point & ${ }^{\circ} \mathrm{C}$ & $2 \pm 0.00$ & $2 \pm 0.00$ & $2 \pm 0.00$ & $*$ & $*$ \\
\hline Cloud point & ${ }^{\circ} \mathrm{C}$ & $8 \pm 0.00$ & $7 \pm 0.00$ & $7 \pm 0.00$ & -3 to 12 & $*$ \\
\hline Oxidative stability & $\mathrm{h}$ & 5.8 & 6.2 & 6.4 & $3 \mathrm{~min}$ & $6 \mathrm{~min}$ \\
\hline Flash point & ${ }^{\circ} \mathrm{C}$ & $153 \pm 2.0$ & $148 \pm 2.0$ & $151 \pm 1.8$ & $93 \mathrm{~min}$ & $120 \mathrm{~min}$ \\
\hline Cetane number & & $52.84 \pm 1.50$ & $52.57 \pm 1.70$ & $52.63 \pm 1.70$ & $47 \mathrm{~min}$ & $51 \mathrm{~min}$ \\
\hline Ash content & $\%$ mass & $0.014 \pm 0.001$ & $0.014 \pm 0.002$ & $0.015 \pm 0.002$ & $0.02 \max$ & $0.02 \max$ \\
\hline Water and sediment & $\% \mathrm{Vol}$ & 0.04 & 0.05 & 0.04 & $0.05 \max$ & $0.05 \max$ \\
\hline Heat of combustion & $\mathrm{Mj} / \mathrm{kg}$ & $42.76 \pm 0.52$ & $42.90 \pm 0.60$ & $43.65 \pm 0.62$ & - & - \\
\hline FFA & $\%$ & 0.14 & 0.17 & 0.09 & $<1 \%$ & $<1 \%$ \\
\hline Yield of Biodiesel & $\%$ & 92.68 & 95.50 & 97.20 & & \\
\hline
\end{tabular}

Iodine value: The iodine value obtained in this study range from $90.50 \pm 1.20 \mathrm{gI}_{2} / 100 \mathrm{~g}$ for $\mathrm{NaOH}$ catalyzed raw biodiesel and $72.42 \pm 1.50 \mathrm{gI}_{2} / 100 \mathrm{~g}$, $72.56 \pm 0.09 \mathrm{gI}_{2} / 100 \mathrm{~g}$ and $70.40 \pm 1.50 \mathrm{gI}_{2} / 100 \mathrm{~g}$ for $\mathrm{NaOH}, \mathrm{KOH}$ and $\mathrm{CaO} / \mathrm{Al}_{2} \mathrm{O}_{3}$ catalyzed degummed biodiesel. The iodine values of all biodiesel are within the EN14214 standard. The lower iodine value of degummed biodiesel means they are more stable to oxidation. The decrease in the iodine value of degummed biodiesel due to degumming process suggests decrease in the degree of unsaturation.

Pour and Cloud point: According to ASTM no limit is specified for pour and cloud point. The reason is that the climate condition in the world vary considerably, thus affecting the needs of biodiesel users in a specific region (Rashed and Anwar, 2008). Pour and cloud points of biodiesel are presented in Tables 2 and 3 . The pour and cloud point of raw biodiesel are $3^{\circ} \mathrm{C}$ and $8^{\circ} \mathrm{C}$ respectively, while those of degummed biodiesel are $2^{\circ} \mathrm{C}$ and $8^{\circ} \mathrm{C}$ for $\mathrm{NaOH}$ and $2^{\circ} \mathrm{C}$ and $7^{\circ} \mathrm{C}$ for both $\mathrm{KOH}$ and $\mathrm{CaO} / \mathrm{Al}_{2} \mathrm{O}_{3}$ catalyzed degummed biodiesel. The biodiesel obtained from degummed oil was observed to have lower cloud and pour point than raw biodiesel.
This might be due to the reduction in degree of unsaturation of the oil after degumming process. In Nigeria the biodiesel sample will tend to retain their flow properties.

Flash point: The flash point of raw biodiesel $\left(158^{\circ} \mathrm{C}\right)$ is higher than that of degummed biodiesel which are $153^{\circ} \mathrm{C}, 148^{\circ} \mathrm{C}$ and $151^{\circ} \mathrm{C}$ for $\mathrm{NaOH}, \mathrm{KOH}$ and $\mathrm{CaO} / \mathrm{Al}_{2} \mathrm{O}_{3}$ biodiesels. All the biodiesels sample have higher flash point than the minimum value specified by ASTM D6751 $\left(130^{\circ} \mathrm{C}\right)$ and $\mathrm{EN}\left(120^{\circ} \mathrm{C}\right)$. The high flash point of the biodiesel samples mean they are safe to handle, easy to transport and safe for storage, they also have lower risk and reduced chance of uncontrolled deterioration (Sanjay, 2013). The degummed biodiesel have lower flash point than the raw biodiesel. This may be attributed to the removal of phospholipids in the oil during degumming process which may have contributed to high flash point observed in the raw biodiesel.

Oxidation stability: Oxidation stability is an important technical issue affecting biodiesel quality (Knothe, 2008). A minimum rancimat induction period of $3 \mathrm{~h}$ 
and $6 \mathrm{~h}$ is defined for biodiesel using ASTM D6751 and EN14214 standards respectively. As provided in Tables 2 and 3 the oxidative stability (OS) of raw and degummed $\mathrm{NaOH}$ catalyzed biodiesel are $4.2 \mathrm{~h}$ and $5.8 \mathrm{~h}$ respectively while the oxidative stability of $\mathrm{KOH}$ and $\mathrm{CaO} / \mathrm{Al}_{2} \mathrm{O}_{3}$ catalyzed degummed biodiesel are $6.2 \mathrm{~h}$ and $6.4 \mathrm{~h}$ respectively. The OS of the raw biodiesel $4.2 \mathrm{hrs}$ is higher than the recommended ASTM D6751 (3h minimum) and lower than that specified by EN14214 (6h minimum), while the OS of the degummed biodiesels were higher than the recommended ASTM D6751 and EN14214 minimum standard except that of $\mathrm{NaOH}$ catalyzed degummed biodiesel (5.8h) which is slightly lower than the EN standard (6h). The percentage increase in the OS of degummed biodiesel might be due to removal of phospholipids during degumming process. Nzai et al., (1999) reported that removal of oil phospholipids result in subsequent removal of iron and copper and improves oil oxidative and flavor stability.

Cetane number: Cetane number provides information about the ignition delay time of a diesel fuel upon injection into the combustion chamber. High cetane number signifies only short delay; between fuel injection and ignition, and this ensure a good cold start behavior and a smooth run of engine (Boz, et al., 2009). The cetane number of $\mathrm{NaOH}$ catalyzed raw biodiesel is $49.78 \pm 1.82$ while that of degummed biodiesels are $52.84 \pm 1.50$ for $\mathrm{NaOH}, 52.57 \pm 1.70$ for $\mathrm{KOH}$ and $52.63 \pm 1.70$ for $\mathrm{CaO} / \mathrm{Al}_{2} \mathrm{O}_{3}$. From the result all biodiesel sample have cetane number that is higher than the minimum standard of 47 set by ASTM D6751 and 51 set by EN 14214 except, the raw biodiesel that have cetane number less than the EN standard but higher than ASTM standard. Cetane number increases with increase in degree of saturation (Adekunle, et al., 2016). The decrease in degree of unsaturation of degummed oil might be the reason for the increase in cetane number of degummed biodiesels.

Ash content: The ash content of $\mathrm{NaOH}$ catalyzed raw and degummed biodiesel are $0.018 \pm 0.002 \%$ by mass and $0.014 \pm 0.001 \%$ by mass respectively. $\mathrm{KOH}$ and $\mathrm{CaO} / \mathrm{Al}_{2} \mathrm{O}_{3}$ catalyzed degummed biodiesel have ash content of $0.014 \pm 0.002$ and $0.015 \pm 0.002$ respectively. Both ASTM D6751 and EN14214 limit the amount of ash content to be maximum 0.02 (\% mass). All the biodiesel from this study have ash content below the maximum limit set by both ASTM D6751 and EN14214. The decrease in the ash content value of degummed biodiesel might be due to removal of phospholipids during degumming process.

Water and sediment: Water content of biodiesel reduces the heat of combustion and will cause corrosion of vital. fuel system components; fuel pumps, injector pumps, fuel tubes etc. more over sediment may consist of suspended rust and dust particles or it may originate from the fuel as insoluble compound during oxidation (Dermibas, 2009; Van Gerpen 2005). ASTM D6751 and EN14214 standards limit the amount of water and sediment to be max 0.05 (\%v). Tables 2 and 3 highlights the water and sediments content of raw and degummed biodiesel. The raw biodiesel have water and sediment value $(0.06 \% \mathrm{v})$ higher than the recommended ASTM and EN standard limit, it may cause corrosion and affect engine performance. The degummed biodiesels have water and sediment value below the maximum limit set by ASTM D6751 and EN14214.

Heat of combustion: The heat of combustion or heating value is not specified in the biodiesel standards by ASTM D6751 and EN14214. However European standard for using biodiesel as heating oil specifies a minimum heating value of $35 \mathrm{mg} / \mathrm{kg}$ (Sokoto et al., 2011). The biodiesel obtain from this study have a heating value of $40.26 \pm 0.70 \mathrm{mg} / \mathrm{kg}$ for raw biodiesel and $42.76 \pm 0.52,42.90 \pm 0.60$ and $42.65 \pm 0.62 \mathrm{mg} / \mathrm{kg}$ for $\mathrm{NaOH}, \mathrm{KOH}$ and $\mathrm{CaO} / \mathrm{Al}_{2} \mathrm{O}_{3}$ catalyzed degummed biodiesel respectively. Biodiesels obtain from degummed oil have higher heat of combustion that the one obtain from the raw oil. Heating value increases with decrease in unsaturation (Sokoto et al., 2011). The increase in heating value of degummed biodiesel might be as a result of decrease in degree of unsaturation after degumming process. Both biodiesel samples can be potential alternative to petroleum diesel based on their heat of combustion.

Conclusion: The oil content of Terminalia catappa was high enough to be classified as economically viable source for biodiesel production. Degummed oils produced higher methyl ester yield (Biodiesel) and fuel properties that meet ASTM D6751 and EN14214 biodiesel standard than the raw oil. $\mathrm{CaO} / \mathrm{Al}_{2} \mathrm{O}_{3}$ catalyst produced higher yield and better quality biodiesel that meet both ASTM D6751 and EN14214 biodiesel standard compared to $\mathrm{NaOH}$ and $\mathrm{KOH}$ catalyst.

Acknowledgment: The author acknowledge the financial support of the Nigerian army and tertiary education trust fund (TETFUND) and Ahmadu Bello University, Zaria for providing the plat form for this research.

\section{REFERENCES}

Adekunle, AS; Oyekunle, JAO; Obisesan, OR; Ojo, OS (2016). Effects of degumming on biodiesel properties of some non-conventional seed oils. Energy Reports, 2, 188-193. 
Adewuyi, A; Oderinde, RA; Ojo, DF (2011). Production of biodiesel from Terminalia catappa seed oil with high free fatty acids using an acidcatalyzed pretreatment step. Inter. J. Sustain. Energy, 30(sup1), S59-S65

Aldo, O; Temu, AK; Ogwok, P; Ntalikwa, JW. (2011). Physicochemical properties of biodiesel from castor and Jatropha oils. Int. J. Renew. Energy Res.

American Oil Chemists' Society (AOCS), 1998. Official methods and recommended practices of the AOCS campaign, Illinois: AOCS press.

ASTM, (2008) Standard specification for biodiesel B100 blend stock for distillate fuels. In Annual book of ASTM standards, ASTM international, west Conshohocken method D6751-08.

Balat, M; Balat, H (2010). Progress in biodiesel processing. Applied energy, 87(6), 1815-1835.

Boz, N; Kara, M; Sunal, O; Alptekin, E; Değirmenbaşi, N (2009). Investigation of the fuel properties of biodiesel produced over an aluminabased solid catalyst. Turkish J. Chem. 33(3), 433442.

Canakci, M; Van Gerpen, JH (2001). Biodiesel production from oils and fats with high free fatty acidsll. Transact. American Soc. Agric. Engineer. 44(6):1429-36.

Cvengros, J (1998). Acidity and corrosiveness of methyl esters of vegetable oils. Eur. J. Lipid Sci. Tech., 100 (2), 41-44

Demirbas, A (2009). Progress and recent trends in biodiesel fuels. Energy Convers. Manage. 50(1), 14-34.

Dos Santos, ICF; De Carvalho, SHV; Solleti, JI; de La Salles, WF; de La, KT.DS; Meneghetti, SMP (2008). Studies of Terminalia catappa L. oil: characterization and biodiesel production. Biores. Technol. 99(14), 6545-6549.

Fukuda, H; Kondo, A; Noda, H (2001). Biodiesel fuel production by transesterification of oils. J. Biosci. Bioengineer. 92(5), 405-416.

Gerpen, JV; Shanks, B; Pruszko, R; Clements, D; Knothe, G (2004). Biodiesel production technology.1617 Cole Boulevard Golden, Co:
National Renewable Energy Laboratory. pp. 15-12, 22-29.

Giwa, S; Ogunbona, C (2014). Sweet almond (Prunus amygdalus" dulcis") seeds as a potential feedstock for Nigerian Biodiesel Automotive Project. Revista Ambiente. Água. 9(1), 37-45.

Knothe G. (2008). Designer\| Biodiesel: Optimizing Fatty Ester Composition to Improve Fuel Properties. Energy and Fuels, 22(2): 1358 - 1364

Knothe, G. (2009). Improving biodiesel fuel properties by modifying fatty ester composition. Energy. Environ. Sci. 2:759-766.

Mahajan, S; Konar, S.K; Boocock, DGB (2006). Determining the acid number of biodiesel. J. Am. Oil Chem. Soc., 83 (6), 567-570

Matos, L; Nzikou, JM; Kimbonguila, A; Ndangui, CB; Pambou-Tobi, NPG; Abena, AA; Desobry, S; (2009). Composition and nutritional properties of seeds and oil from Terminalia catappa L. Adv. J. Food Sci. Technol. (1), 72-77.

Meher, LC; Sagar, DV; Naik, SN (2006). Technical aspects of biodiesel production by transesterification - a review. Renewable and Sustainable Energy Review, 10: 248-68.

Ng, S; Lasekan, O; Muhammad, KS; Hussain, N; Sulaiman, R (2015). Physicochemical properties of Malaysian-grown tropical almond nuts (Terminalia catappa).Journal of food science and technology, 52(10), 6623-6630.

Nzai, JM; Proctor, A (1999). Soy lecithin phospholipid determination by fourier transform infrared spectroscopy and the acid digest/arseno-molybdate method: A comparative study. Journal of the American Oil Chemists' Society, 76(1), 61-66.

Odeigah, E; Rimfiel, BJ; Robiah, Y (2012). Factors affecting the cold flow behaviour of biodiesel and methods for improvement - A Review: Pertanika Journal Science and Technology, 20(1): 1 - 14.

Oderinde, RA (1998). Metal and oil characterization of Terminalia catappa. L. Riv. Ital. Grasse., 75, 361-362.

Oseni, MI; Obetta, SE;Orukotan, FV (2012).Evaluation of fatty acids profile of ethyl sesters of yellow oleander and groundnut oils as 
biodiesel feedstock. American Journal of Scientific and Industrial Research, 3(2): 62-68

Raj, FRMS; Sahayaraj, JW (2010, November). A comparative study over alternative fuel (biodiesel) for environmental friendly emission. In Recent Advances in Space Technology Services and Climate Change (RSTSCC), 2010 (pp. 80-86). IEEE.

Rashid, U; Anwar, F (2008). Production of biodiesel through optimized alkaline-catalyzed transesterification of rapeseed oil. Fuel, 87(3), 265273.

Sanjay, B. (2013). Non-Conventional Seed Oils as Potential Feedstocks for Future Biodiesel Industries: A Brief Review. Research Journal of Chemical Sciences, 3(5): 99-103.

Shahriar, S; Erkan, T. (2009). When will fossil fuel reserves be diminished? Energy Policy, 7(1): 181189.
Sokoto, MA; Hassan, LG; Dangoggo, SM; Ahmad, HG; and Uba, A (2011). Influence of fatty acid methyl esters on fuel properties of biodiesel produced from the seeds oil of Curcubita pepo. Nige. J. Basic Appl. Sci. 19(1) 81-85

Van Gerpen, J (2005). Biodiesel processing and production. Fuel processing technology, 86(10), 1097-1107.

Voca, N; Kricka, T; Janusic, V; Jukic, Z; Martin, A; Kis, D (2008). Fuel properties of biodiesel produced from different raw materials in Croatia. J. Mech. Engineer. 54(3): 232-244 